\title{
A new ethical approach to abortion and its implications for the euthanasia dispute ${ }^{1}$
}

\author{
R F R Gardner Department of Gynaecology, Ryhope General Hospital, Sunderland
}

\begin{abstract}
Mr Gardner, a practising gynaecologist who is necessarily involved with abortion, suggests a view of the fetus which is between the positions commonly held: the fetus is a mass of cells, the fetus is a person from the moment of conception. He considers that from the moment of conception there is established a maternal-fetal unity. In that state the previable fetus is not an individual but is on the way to that status.

The writer goes on to differentiate between the moral positions of the advocates of abortion and of euthanasia. Already legal safeguards for those antipathetic to abortion have been eroded in practice and so likewise would those be if the Euthanasia Bill were to become law.
\end{abstract}

Even before the Abortion Bill was mooted most gynaecologists had performed an occasional abortion for women whose survival would have been jeopardized by a continued pregnancy, perhaps on account of renal failure. However, as far back as the trial of Alec Bourne (1938) it had been established that physical survival was not the only criterion. In addressing the jury on that occasion, Mr Justice MacNaughten said, 'If the probable result of the continuation of the pregnancy would indeed make the woman a physical wreck or a mental wreck... then the operation was to preserve the life of the mother.' We have come a long way since then, and we do not need to be persuaded that an assessment of the mental state of the woman is essential in considering abortion.

No sooner were doctors involved, not occasionally but almost daily, in considering these patients than we realized that these criteria were still inadequate. The patient presenting is not any woman she is this woman who is the centre of a network of relationships - to the other children of the marriage, to her husband, to her parents. On some occasions these relationships are so onerous as to make the bearing of another child a most formidable undertaking. It was a Roman Catholic professor of moral philosophy who stated, 'The mother is not a physical reality merely, not even a psycho-physical reality, but a socio-psycho-physical reality' (McDonagh, 1968).

'This paper is the substance of a recent lecture given to the Newcastle Medical Group.
If it is agreed that all these factors in a woman's make-up demand attention, there can be no objections to the affirmation that even this description is inadequate and a woman must be considered as a whole person - a socio-psycho-physicospiritual reality. It is indeed the failure to grasp this fact that makes much of the writing, the discussion and the statistics inadequate. So, as soon as a speaker says, "I cannot take into account "spiritual" factors', or words to this effect, however interesting his comments or apparently cogent his arguments, they are not scientifically valid, being incomplete.

The mistake is to confuse psychiatric and spiritual sequelae. It is possible to quantify admissions to or outpatient attendance at psychiatric units, but doctors do not have the statistics for the confessional, or for the numbers of women who exclude themselves from the sacraments or who weep in their pastor's study. I should like to commend too my colleagues the techniques of putting this ques tion to the patient at the follow-up visit six weekse after an abortion, 'If you could put the clock back' and you were in that chair at your original appointment, would you still ask for termination?' Or when, in taking a gynaecological history, the patient mentions a termination on some occasion, perhaps years before, ask, 'Did we do the right thing then?'

Of the importance of considering the spiritual factor, I have hinted at one answer: the sizeable minority of women who later regret the termination. There are two other reasons. First, the other factors to which we rightly pay so much attention: health, emotions, social circumstances - all operate for a limited time be it weeks or decades. The spiritual factor affects the central and eternal aspect of the woman and cannot be measured on a mere terrestrial time scale. Secondly, the doctor's or the nurse's own physical, social and mental life is not usually very closely involved in the abortion. But at the level of conscience they are as deeply involved as is the woman, being equally accountable.

\section{What is being done in abortion?}

Whether or not this is important turns on the answer we give to the question, 'What actually is being done in abortion: the killing of a child or the removal of some trophoblastic tissue?' Discussion has polarized into two positions, each of which I believe to be inadequate. 
THE FETUS IS A MASS OF CELLS INSIDE THE MOTHER

There is the viewpoint that the fetus is merely a mass of cells inside the mother. As an obstetrician I could wish this were true as it would save us the problems associated with a fetus and mother of incompatible blood groups, and probably avoid many cases of toxaemia. However, the slightest acquaintance with embryology shows that the fetus is genetically different from the mother, growing hour by hour from the initial fertilized ovum towards the 200 million specialized cells which make up the adult human individual. The 'mere piece of maternal tissue' argument is invalid. And I for one do not believe for a moment that many thinking people accept it even when they are peddling the argument for polemic purposes. I think my agnostic friend is more typical. When, having already had two children herself and then a surviving mongol, she became unintentionally pregnant she was offered an abortion. She wrote to me: 'In theory I believe the fetus is merely a collection of cells till about five months, but when I became pregnant mine was a baby from the first missed period.'

\section{THE FETUS IS A PERSON FROM CONCEPTION}

The opposite point of view is that the fetus is a person from conception, using its mother more or less as an incubator. There is something to be said for this concept from the time of viability, but at the stage when abortion is being considered, in my practice at any rate, viability is months away. It is customary to talk of the placenta as an organ of respiration and excretion - as the cut-off frontier which clearly demarcates fetus from mother. Yet this is too simplistic an argument, as the real organs of fetal respiration are the maternal lungs and of excretion the maternal kidneys. At this stage the fetus is inseparably entwined with the mother and cannot be thought of as an individual.

\section{The maternal-fetal unity}

I wish therefore to break up this polarization of attitudes and introduce a third approach: that we no longer think of the pregnant woman as a woman with an appendage, nor merely as a maternal incubator but that we consider the maternal-fetal unity. This is logical. The problem is not that of a woman: it is the problem of this pregnant woman. If it were not for her current link to this fetus she would not be in the care of an obstetrician. Similarly the problem is not that of antenatal paediatrics it is still of this fetus in this woman. And I have employed the particle 'this' repeatedly to emphasize the importance of the particular nature of their circumstances. To some of you this suggestion will appear to be merely a question of semantics. It matters for two reasons.

First if one holds the common view that the fetus is an independent being in its own right, but in the exceptional circumstances of dire need of the mothe or the family, may be aborted, then are you no? saying that one human being can and should bef snuffed out for the good of another human being op social group? If - holding that view of the fetus - you believe that abortion can ever be justified then is no infanticide justified? Is not euthanasia justified given sufficiently good grounds? The weak can go te the wall, and when shortages come then the popula tion can legitimately, if regretfully, be decimated Paul Ramsay of Princeton has already made this point. He comments (1973) that within a few months of the publication of Daniel Callahan's monument $\vec{\Phi}$ study of the issues bearing on abortion (1970) the moral arguments used there were being cited iff support of euthanasia. If, however, as I suggest, we see the abortion issue in terms of the maternal-feta unity and argue for the sacrifice of one part of that $\vec{t}$ unity, a part which is not yet an individual, the argument cannot be carried over in favour of infanticide and euthanasia.

The distinction that I have made as to viability is crucial. The viable fetus, although still helpless and in need of continual attention, can obtain suct help from a variety of sources. Problems of that particular mother's health, emotions and socios conditions are not central when there are foster mothers available. The issues that should b $\overrightarrow{0}$ weighed are those of the child, however premate्fes who becomes an individual, 'ensouled' if you the term, at the moment of live birth.

There is a second reason, that I feel it is importan to decide on the status of the fetus whose abortio is being considered. A laissez-faire attitude cas lead us all to disaster. Hardin (1968), an America supporter of a liberal abortion policy, has stated? 'Whether the fetus is or is not a human being is a matter of definition, not fact, and we can define an way we wish.' We know what followed for German Jews when Hitler redefined their human status? We are angered at the way in which the Bantu are defined by some Afrikanders. The Nuer, a Nilo 3 . Hamitic people of the Sudan, are said to define 8 congenitally malformed newborn child as a hippo potamus and therefore place him in the rivero Careless and care-free definitions are not admissible To Hardin, Daniel Callahan (1970) wisely retortedo 'The enunciated principle of defining as one wishes. provides no philosophical basis for distinguishing between abortion and infanticide. A power group in society could by use of the principle define the्w chronically sick, the senile, the elderly as nono human and thus justify the taking of their lives.' By the same token the definition 'human' can be tailored to any desired policy so that any being is 'non-human' whom it is found socially useful to define as 'non-human'.

Definition is important. I hope I have shown tha giving the fetus too exalted a definition means that abortion is antenatal infanticide and support is 
given to euthanasia, whereas to consider definitions unimportant also leads to euthanasia and remorselessly to Belsen.

\section{A third view of the status of the fetus}

My own belief as to the status of the fetus is not a case of arguing backwards to avoid the risk we now see of supporting euthanasia: I spelt those out before these risks were realized (Gardner, 1972). Although I do not myself consider a previable fetus as an individual, as a person with a soul, I would emphasize that the fetus is on the way to that status. The considerable risk, perhaps as high as 50 per cent, of spontaneous miscarriage is passed by the time the mother comes with her request for abortion. The fetus has been disparagingly likened to a mere blueprint: it is a blueprint in the act of transforming itself into a house, a transition which will be satisfactorily completed if it is left merely undisturbed. It is not a mere acorn: but is rooted, pushing its shoots upwards to become an oak. It is more, it is on its way to becoming a person and therefore always to be treated with respect and anxious care.

\section{Differences between abortion and euthanasia}

We have seen the importance of asking ourselves, 'What are we doing when we perform an abortion?' And we can achieve clarity still further by asking, 'Why are we performing this abortion?' Here the difference between abortion and euthanasia is very clear. Abortion is a positive act directed towards the life of the mother in all its connotations. Were the pregnancy further advanced the baby would be extracted (perhaps by Caesarean section) and cared for elsewhere, and so the mother would be relieved of this burden threatening her life. However, the pregnancy is too early and that positive aim can only be achieved by the removal of the unwitting aggressor, the fetus. The hoped-for result is the enrichment of the woman and her family. By contrast euthanasia as at present advocated is purely negative. There is no positive good to be achieved, no enrichment.

\section{Patterns laid down by the Abortion Act}

I am anxious to dissociate abortion from euthanasia because I believe the latter to be utterly wrong although I do not propose to discuss the ethics of it here. Despite these differences any Act of Parliament, however carefully framed, that would permit euthanasia on the most narrowly defined grounds will follow the pattern of the Abortion Act. It will suffer erosion. If it is in the nature of malignant disease to eat into tissue, to disorganize the architecture of the cell, and so to destroy the function of an organ, then the 1967 Abortion Act is suffering from cancer. This statement is borne out by a reading of the debates in the House of Commons as recorded in Hansard and in the early literature of the Abortion Law Reform Association and in David Steel's introduction to the volume by Hindell and Sim, Abortion law reformed (197I). We should ask ourselves if the present practice of abortion in Britain bears any resemblance to that practice intended by our legislators when they passed the Act.

Our local hospital abortion committee approves the great majority of requests brought to it but after careful consideration we refused recently a request for abortion from a 17-year-old girl illegitimately pregnant. She thought that it would be 'the best way out', but after considering the details we could not see how by any stretch of the imagination she fitted into the provisions of the Act so we rejected her request. If you are annoyed to learn of this decision my contention is proved that in the view of many people the so long discussed and so carefully considered clauses of the Act have no longer any relevance. And so it would be with a Euthanasia Act. Let such an Act, it will be argued, be restricted to those who, while in their right mind, have signed a request. Within a few months someone would say, 'Look at those paralysed, incontinent, decerebrate old men. If they could be given a brief five minutes of consciousness, with the certainty of thereafter lapsing permanently int their stupor, would they not sign the form - of course they would - let their relatives do for them what the patient would really wish.' That agreed, within a month someone else would say, 'But to expect relatives to make this decision is to impose an impossible emotional burden; let us authorize an official to do this without distressing them.' Naturally parallel arguments would be advanced for the congenitally damaged neonates. It would then be suggested that the problem of approval for the euthanasia of the conscious but incapacitated aged would be even more distressing, and therefore it would be vital to relieve relatives of any involvement in this and have it arranged by some distant office.

\section{Vain promises of safeguards}

The Abortion Act (1967) section 4 subsection I includes the words: "no person shall be under any duty, whether by contract or by any statutory or other legal requirement, to participate in any treatment authorized by this Act to which he has a conscientious objection.' And yet it is well known that within six years of the passage of that Act it is almost impossible for any gynaecologist to become a consultant unless he agrees to perform abortions. The promised safeguards entrenched in the law have been over-ridden, apparently with the blessing of the Department of Health and Social 
Services.

The unsuccessful Euthanasia Bill 1969 contained exactly the same safeguards word for word for conscientious objectors to opt out of involvement in euthanasia. Unless separate euthanasia units and the appropriate consultants were to be provided, and this would surely destroy much of the so-called benefit, euthanasia would be administered in the main units of our hospitals - in the geriatric, surgical, medical, gynaecological, and cardiothoracic departments, to name only the obvious ones. It is then inevitable (and I use that word deliberately) that only doctors would be appointed to these departments who would be prepared to cooperate. To believe the assurances that safeguards would be introduced would be to delude oneself. Neither in this proposed Euthanasia Act nor in any amendments to the Abortion Act are the safeguards to conscience likely to remain secure for five minutes.

\section{Pressures on the patient}

Experience of the Abortion Act has taught a third practical lesson. A certain number of requests are rejected in our unit because in one or other of the separate interviews the woman has with the gynaecologist and with the social worker it comes to light that she herself is not the prime mover in this request. She is being pressurized by mother-in-law, or by mother who is not willing to have a baby in the house, or by the husband who will miss his wife's earnings. The woman's relief when her request for termination is refused is apparent and she frequently admits that she is anxious to continue the pregnancy. I am convinced that this is the tip of the iceberg and for every woman who is pushed into a consulting room there are many who manage to withstand the pressures at home. They did not have to do this before 1967 but the existence of the Act and the option of termination has introduced a new element of doubt and of dissension, even when the pregnancy was planned. Today there are in Britain many tens of thousands of women, legitimately pregnant, in turmoil because this option has to be considered.

If euthanasia becomes legal the crippled, the aged, or the housebound invalid is going remorselessly to be subjected to similar doubts and tensions, and similar tensions and questions will afflict their relatives and those looking after them.

In the writer's view of the status of the previable fetus and of the intention of the operator, abortion is not euthanasia. Nevertheless for practical as well as ethical reasons set out in this paper no Euthanasia Bill must ever reach the Statute Book.

\section{References}

Bourne, A (1963). A Doctor's Creed: Memoirs of a Gynaecologist. Gollancz, London.
Callahan, D (1970). Abortion: Law, Choice or Moralit Collier-Macmillan, London.

Gardner, R F R (1972). Abortion, the Personal Dilemm $\vec{\oplus}$ Paternoster Press, Exeter.

Hardin, G (1968). Abortion or compulsory pregnancy fournal of Marriage and the Family.

Hindell, $\mathrm{K}$, and Simms, $M$ (1971). Abortion L $L$ Reformed. Peter Owen, London.

McDonagh, E (1968). Ethical problems in abortio Theology, 71, 393.

Ramsay, P (1973). Abortion: A review article. The Thomist, 37, 174 .

\section{Commentary}

\section{Philip R Myerscough Royal Infirmary,} Edinburgh

The Abortion (Amendment) Bill, introduced $\vec{b}$ Mr James White, MP, is arousing a great de of controversy. Regrettably the issues have becorme polarized around two extreme views: either abortion is a good thing and therefore any decrease in its frequency is to be deplored or opposed, abortion is a bad thing and therefore any reduction in its incidence, however accomplished, is a gai $\overrightarrow{\mathrm{B}_{\text {. }}}$ It is relevant to comment that both these opposed attitudes tend to be associated with the biological absurd view that the acquisition by the embryo. fetus of human status (with an implied right protection) takes place abruptly at a particular instant in time, that is, either at the moment of conception or at the moment of birth. This is sharp contrast with all that is known of the gradual processes by which embryogenesis, growth and functional development occur as a continuum.

\section{The 28th week - an ethical watershed?}

At present the fetus does not enjoy 'protected" status until the end of the 28th week and abortiog can be lawful up to that point in time. But is thes arbitrary point of administrative definition really ethical watershed? Dr Gardner has argued that the attainment of 'viability' should be regarded as the crucial consideration on assigning human status to the unborn. However, with technical advances survival of infants of extremely low birth weigh becomes commoner and this argument points now to the 20th rather than to the 28th week, as tidie Abortion (Amendment) Bill proposes. 